\title{
分割型ホログラムによるレーザー集光スポットの多重パターニング
}

\author{
末田 敬一 ${ }^{1}$ ，椿本 孝治 ${ }^{2}$ \\ 1福井県産業支援センター（９10-0102 福井市川合熟塚町61字北稲田10) \\ 2大阪大学 レーザー核融合研究センター（５565-0871 大阪府吹田市山田丘2-6)
}

\section{Multiple Patterning of Laser Focus Spot Using a Segmented Kinoform Phase Plate}

\author{
Keiichi SUEDA ${ }^{1}$ and Koji TSUBAKIMOTO ${ }^{2}$ \\ ${ }^{1}$ Research Center for Industrial Science and Technology, 61-10 Kawaiwashizuka, Fukui 910-0102 \\ ${ }^{2}$ Institute of Laser Engineering, 2-6 Yamadaoka, Suita, Osaka 565-0871
}

(Received October 15, 2003)

\begin{abstract}
An important technique required in the application of laser systems to fusion is the ability to generate high energy to satisfy the conditions for self-ignition and to improve the uniformity of laser irradiation. To achieve this result, it is necessary to introduce a kinoform phase plate (KPP) that is able to produce an optimum envelope profile. However, a KPP is sensitive to beam aberrations caused by the nonlinear refractive index in optical components. To overcome this problem we have developed a multi-segmented KPP and demonstrated its usefulness and strength against phase distortions by numerical simulations.
\end{abstract}

Key Words: Kinoform phase plate, Computer-generated hologram, Laser fusion

1.はじめに

直接照射型レーザー核融合では，微小燃料ペレットを 大出力レーザー光で照射してペレット表面から球対称的 にプラズマを噴出させ，その反作用で内部の燃料水素を 圧縮する。その結果, 中心部は高温高密度状態に達し て，ごく短時間の間に核融合反応が進行し，大量のエネ ルギーが放出される1)。このため, 燃料ペレットの圧縮過 程には高い球対称性が要求され，照射レーザー強度の不 均一は, アブレーション圧力の空間的不均一を引き起こ し，またターゲット加速の初期段階においてターゲット 表面の凹凸として刻印され, それが流体力学的不安定性 により成長する。このような圧縮不均一は燃料の自己点 火に必要なレーザーエネルギーを大幅に増大させる。

そこで，照射に用いるレーザー光には，高いレーザー 強度だけでなく優れた均一性が要求される。 大阪大学 レーザー核融合研究センターでは, ランダム位相板 ${ }^{2)}$ と呼 ばれる均一照射技術が導入され, 球状ターゲットの高密 度圧縮を実現した。しかし，ランダム位相板の遠視野パ ターンはBesinc ${ }^{2}(r)$ 関数型のためにスポットに広い裾を有 しており，エネルギーの利用効率が低くい。 また，発生 したプラズマによるレーザー光の吸収分布を考慮すると 照射レーザーの接平面での集光パターンがフラットトッ プ形状に近いほど, 高い吸収一様性が得られることが報 告されている3).これらの問題を解決するには, 集光ス ポットにおける集光包絡線形状を制御することが不可欠 である。
筆者らは照射一様性の向上を目的として，位相ホログ ラムの原理を応用しレーザー光の位相分布を制御するこ とで，集光スポットの集光包絡線形状を任意に制御する ことができる位相板，すなわちキノフォルム位相板 (Kinoform Phase Plate: KPP) ${ }^{4)}$ の開発を行った，従来，KPP

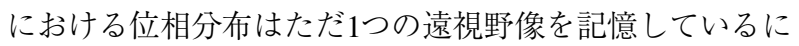
過ぎなかったが，入力のパターン (近視野像)を変化させ， その各々に対応して集光パターンを生成するように位相 分布を設計することで，一枚の位相板に複数の集光パ ターンを記憶させることに成功した。このKPPを用いる と, 入力ビームを時間的に変化させることで, 複数の集 光パターンを再生あるいは時間的に変化させることが可 能である. また, KPPはその構造上, 入力ビームの位相䛊 差(波面歪み)に極めて脆弱であるが, この設計アルゴリズ ムを用いてKPPをセグメント化することにより, 近視野領 域での位相歪みに耐力を有するパターン再生も可能とな る.

本稿では一枚のKPPに複数の集光パターンを記憶させる 設計アルゴリズムについて説明し，そのアルゴリズムを用 いて設計したKPPによる集光パターンの動的制御と，近視 野領域での位相誤差に耐力を有するKPPについて述べる.

\section{KPPによる包絡線制御}

\subsection{KPPの機能}

KPPを通過したレーザー光の集光パターンはFresnelKirchhoff式のFraunhofer近似式を用いて計算することがで 
き, $\mathrm{KPP}($ 位相分布 : $\phi(u, v))$ 通過後のレーザー光(波長： $\lambda$, 波数: $k)$ の複素振幅を $u(u, v)$ とすると, このビームを レンズ (焦点距離： $f$ )によって集光したときの遠視野での 複素振幅 $U(x, y)$ は

$$
\begin{gathered}
U(x, y)=\frac{\exp (i 2 k f)}{i \lambda f} \iint|u(u, v)| \exp [\phi(u, v)] . \\
\exp \left[i 2 \pi\left(u \frac{x}{\lambda f}+v \frac{y}{\lambda f}\right)\right] \mathrm{d} u \mathrm{~d} v
\end{gathered}
$$

となる。 $(x, y)$ は集光面での座標を表し,$\quad(u, v)$ はKPP面 の座標を表す。また，KPPは基板上に半波長 $(\lambda / 2)$ の位相 差を持つ正方形の位相膜エレメントを2次元アレイ状に配 置することで作られるが，位相膜による位相遅れ を $t$, 波長 $\lambda$ に対する屈折率を $n$ とすれば, $\phi=\frac{2 \pi}{\lambda} t(n-1)$ に より与えられる。よって, 遠視野で強度分布 $|U(x, y)|$ の 集光パターンが得るには，KPPの位相分布 $\phi(u, v)$, すなわ ち位相膜の分布を適当に選ぶことにより可能であり， $U$ $(x, y) \mid$ から $\phi(u, v)$ を求める問題に帰着できる. Fig. 1にKPP の設計例を示す。近視野の入力パターンは直径 $320 \mathrm{~mm}$ の 円形開口のフラットトップ形状とし，設計の集光パター ンの強度分布を, 22 次のスーパーガウシアン (半径 250 $\mu \mathrm{m})$ とした.（a）はそのときのKPPの位相分布を表し，（b） はこのKPPを通過した光を集光したときの集光プロファイ ルを表す。

\subsection{KPPの設計アルゴリズム}

今 $2 つ の$ 複素振幅関数 $U(x, y), u(u, v)$ が

$$
\begin{aligned}
& U(x, y)=|U(x, y)| \exp [i \theta(x, y)] \\
& u(u, v)=|u(u, v)| \exp [i \phi(u, v)]
\end{aligned}
$$

と表され，これらがフーリエ変換の関係で結ばれており， $|U(x, y)| 2$ が観測可能な量として既知な場合に $|U(x, y)|$ か
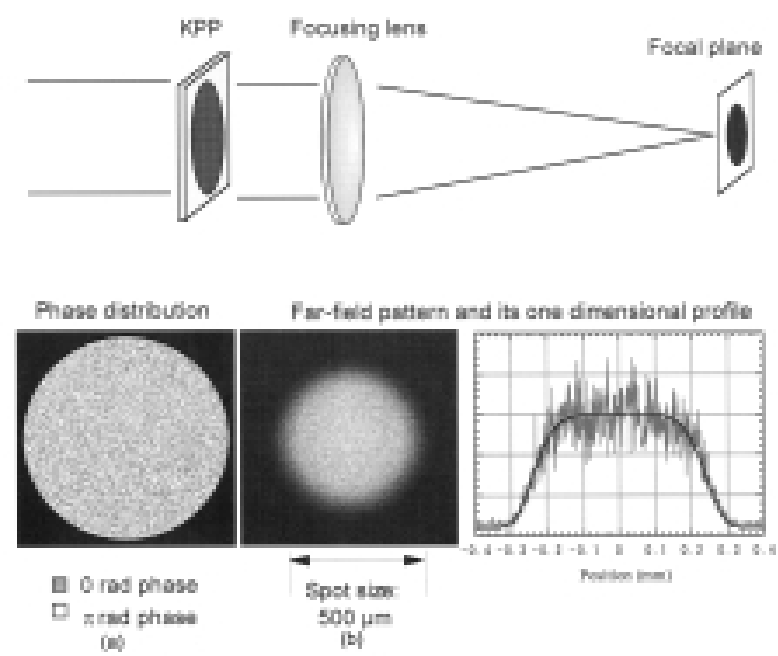

Fig. 1 Irradiance profile control using a kinoform phase plate. (a) Phase distribution. (b) Far-field pattern and its one dimensional profile.
$ら \phi(u, v)$ を求める問題を位相回復問題といい, 種々の手法 が提案されている．核融合レーザー用の設計を考えた場 合，ある複素振幅関数の絶対值が与えられたとき，その 複素振幅関数のフーリ工変換の絶対值が望みの值になる ようにもとの関数の位相を求める必要がある。そこで像 再生を目的とした計算機ホログラムに適したアルゴリズ ムである反復フーリエ変換法5-10)により位相の決定を行っ た. 反復フーリエ变換法とは, 近視野像と遠視野像の複 素振幅がフーリエ变換の関係で結ばれているとき, 像の 振幅分布の絶対值とそのフーリエ変換の絶対值から両方 の位相を求めることに帰着する方法である。このアルゴ

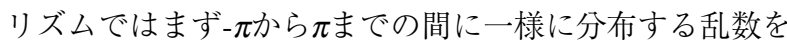
初期位相とし, これを既知の遠視野像と組み合わせて初 期推定複素振幅を作る。これをフーリエ変換し, 変換後 の絶対值部分は既知の遠視野における強度分布で置き換 え, 位相はその元の状態に保存しておく.この結果を逆 フーリエ変換した後，絶対值部分を近視野領域における 強度分布で置換し，位相はそのまま残す。以下同様の方 法を繰り返して誤差を減らし解を収束させる. Fig. 2 は反 復フーリエ変換法のフローチャートである。 ここで $u(u$, v)は近視野の複素振幅, $\phi(u, v)$ はKPPの位相分布である. よって $|u(x, v)|^{2}$ はビームの強度であり既知である。ま た, $U(x, y)$ は遠視野の複素振幅, $\theta(x, y)$ は位相である. 計算の流れは以下のように進める.

(1) $-\pi$ から $\pi$ の間に一様分布する乱数を初期位相 $\phi_{0}(u, v)$ とし, 近視野の振幅 $|u(u, v)|$ と組み合わせて複素振幅 $|u(u, v)| \exp \left[i \phi_{0}(u, v)\right]$ を作る.

(2) これをフーリエ変換して遠視野の複素振幅 $\left|U^{\prime}(x, y)\right| \exp [i \theta(x, y)]$ を求める.

(3) その振幅 $\left|U^{\prime}(x, y)\right|$ を設計の集光パターンの振幅

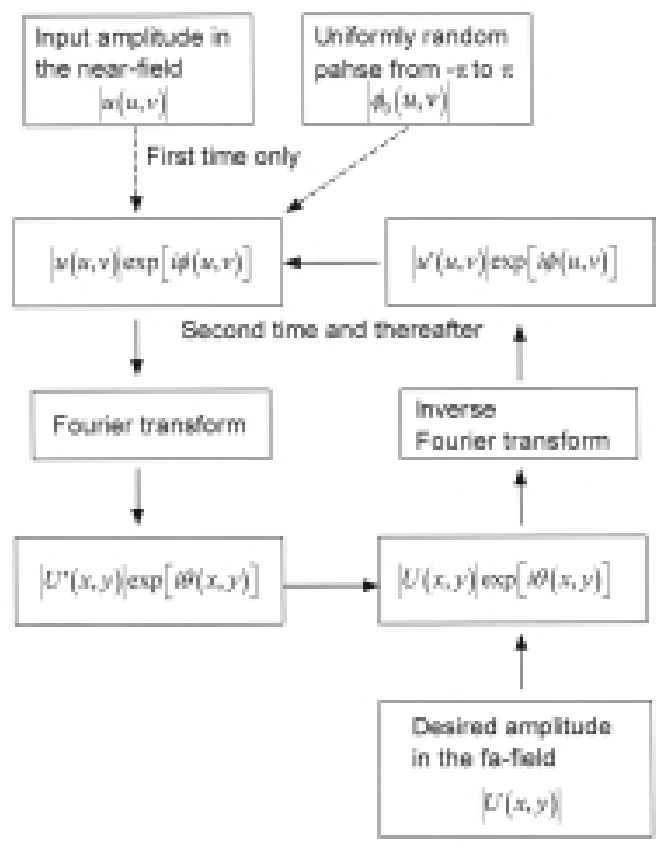

Fig. 2 Phase recovery algorithm for a kinoform phase plate.

レーザー研究 2004 年 4 月 
$|U(x, y)|$ に置き換え，位相 $\theta(x, y)$ はそのまま残す。

(4)この結果を逆フーリエ変換して近視野の複素振幅 $\left|u^{\prime}(u, v)\right| \exp [i \phi(u, v)]$ を求める。

(5) 振幅 $\left|u^{\prime}(u, v)\right|$ は近視野の入力の振幅 $|u(u, v)|$ に置き 換える.

以上の (2)から (5)の操作を繰り返すことによって，位相 分布を収束させる。 また, $U(x, y), U^{\prime}(x, y)$ はそれぞれ

$\sum_{j=1}^{N} \sum_{k=1}^{N}|U(x, y)|=1, \quad \sum_{j=1}^{N} \sum_{k=1}^{N}\left|U^{\prime}(x, y)\right|=1$ として規格化した.

一般的にKPPは多段ステップで遠視野像を制御するが，現 有の製作技術で大口径化が容易なのは2段階，すなわちバ イナリー (0とれの位相分布を与える)である。 そこで連続 的位相分布に対する反復フーリエ変換法にバイナリー化 のアルゴリズムを追加した．量子化されたKPPの設計アル ゴリズムでは, 上述の $(5)$ の行程に打いて位相 $\phi(u, v)$ を移 すときに，階調数を $N$ としたとき， $-\pi$ から $\pi$ の間で $\phi(u, v)$ を $N$ 等分することにより $\phi_{\mathrm{d}}(u, v)$ を得る。そして繰り返し 数が増加するとともに $N$ をしたいに下げていき最後に 2 值 化し，最終的に0とれの位相分布を得る。

\section{3. 集光スポットの多重パターニング}

従来，KPPにおける位相分布はただ一つの遠視野像を記 憶しているに過ぎなかった。これに対して本研究では入 カのパターン (近視野像)を変化させ, その各々に対応して 集光パターンを生成するように位相分布を設計すること で，一枚の位相板に複数の集光パターンを記憶させるこ とを試みた。パターン設計手法を次に示す。直径が異な る2つの入力ビーム $\mathrm{A}\left(\right.$ ビーム直径 $\left.D_{\mathrm{a}}\right), \mathrm{B}\left(\right.$ ビーム直径 $D_{\mathrm{b}}>$ $\left.D_{\mathrm{a}}\right)$ を仮定し，それぞれが生成する遠視野像をそれぞれ $\mathrm{F}_{\mathrm{A}}, \mathrm{F}_{\mathrm{B}}$ とする。各々の位相分布の決定には2.2で述べた計 算方法を用いる.

(1) 最初に入力ビームAがパターン $\mathrm{F}_{\mathrm{A}}$ を再生するように 位相分布を決定する。このとき位相回復アルゴリズムに おける位相板面上の計算領域は径が $D_{\mathrm{a}}$ の領域 (領域A)にお いてのみである.

(2) 入力ビームAに対する位相分布が決定された後, 領 域Aの位相分布を固定する。

(3) 位相決定は位相板面上において直径が $D_{\mathrm{b}}$ の) 領域 (領 域B)で行われるが, 領域(A)の位相分布は変化させず領域 (B-A)からの光波によってビームAが構成する遠視野像 $\mathrm{F}_{\mathrm{A}}$ をうち消しつつ， $\mathrm{F}_{\mathrm{B}}$ を再生するように位相分布を決定し ていく.

Fig. 3に1枚のKPPに2枚のパターンが記憶された例を示 す．（a）はその位相分布，(b)は入力ビーム A に対する遠 視野像を，(c) は入力ビーム B に対する遠視野像を示して いる. 入力ビームAでは遠視野に打いてアルファベットA

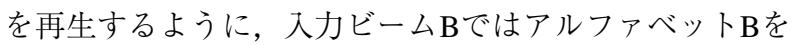
再生するように設計した。メッシュサイズは $128 \times 128$ ，入 カビームの強度比は $1: 1$ のフラットトップパターン, ビーム径比率はA:B = 1:2である.この結果，1枚のKPPに
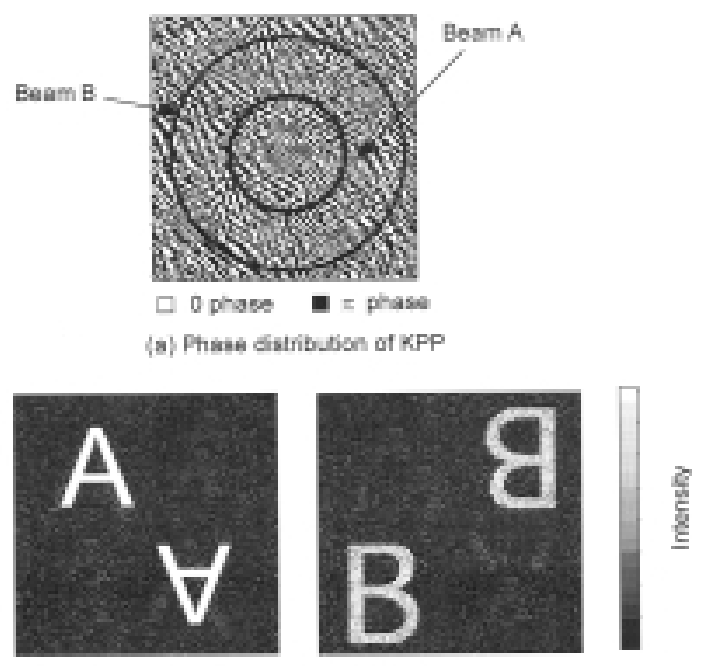

(b) Far-feid patter (Besm A) (c) Far-field patiar (Beam B)

Fig. 3 Multiple patterning of a laser focus spot by using of a segmented kinoform phase plate.

複数の独立したパターンを記憶することが可能であるこ とがわかる.

\section{4. 集光パターンの動的制御}

慣性核融合において高いターゲット利得を達成するた めには，燃料を効率よく高密度に圧縮することが必要不 可欠である。従って燃料はできるだけ低い温度(低エント ロピー)を保ちつつ加速・圧縮されなければならない。こ の様な圧縮過程を実現するための駆動力となるレーザー の波形は，高精度に調整されることになる。この波形整 形されたレーザーパルスはテーラードパルスとも呼ば れ, その基本的特徵は, レーザー出力が最初(フット部)は 極めて低く抑えられ，時間とともに急激に増大する(主パ ルス)というものである。しかし，流体不安定性による擾 乱の成長はテーラードパルスでは大きく, 離散パルスに よる圧縮の方が小さいため, 両者の妥協点として階段状 のパルス波形の導入が思案されている。このように断熱 圧縮と流体力学不安定性から要請されるパルス形状を実 現することは重要である。しかし，フット部と主パルス のコントラストが100を越えるような場合, 多ビームレー ザー間のパワーバランスの調整が極めて困難である。そ こで, もしも爆縮に追従して集光スポット径を変化させ ることができればエネルギー効率だけでなく, 波形整形 の容易さやパワーバランスの精度向上の観点からも有効 である。

そこで3項で述べた1枚のKPPに複数の位相分布を記憶さ せることが可能であるという原理を応用して集光パター ンの動的制御のシミュレーションを行った。具体的な方 法は, 入力ビームの口径と強度を時間的に変化させ，そ の各々に対応して集光パターン(この場合は爆縮に追従し て集光スポット径が収縮していくように設計)を生成する ように位相分布を設計する。そしてパルススタッキング の技術を用いて入カレーザービームの口径打よび強度を 時間的に制御すれば，集光パターンを時間的に制御する 
ことが可能である.

実際に核融合用レーザーに導入する場合を想定して，3 パターンの記憶を試みた。設計には3項で述べた設計アル ゴリズムを繰り返し用い, 設計条件としては, 入射ビー ムは口径 $320 \mathrm{~mm}$ の円形開口フラットトップパターン，そ の波長は526.5 nm, 遠視野領域を $1 \mathrm{~mm} \times 1 \mathrm{~mm}$, 計算機中 ではメッシュを $512 \times 512$ に分割し，遠視野における集光パ ターンの強度分布は直径が500 $\mu \mathrm{m}$ から順次収縮するフ ラットトップを仮定した. 集光パターンの強度分布を評

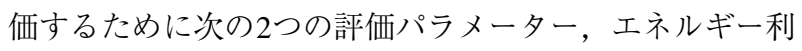
用効率 (入射エネルギーに対してターゲット表面に集光さ れるエネルギーの割合) と設計遠視野パターンからの誤差 を用いた。誤差は

$$
\sqrt{\sum_{j=1}^{N} \sum_{k=1}^{N}\left|I_{d}(j, k)-I(j, k)\right|^{2}} / I_{d}(j, k)
$$

と定義する．ただし $I_{\mathrm{d}}(j, k)$ は設計パターンの強度分布を表 し, $I(j, k)$ は集光パターンの強度分布を表す.

また， $I(j, k), I_{\mathrm{d}}(j, k)$ はそれぞれ

$$
\sum_{j=1}^{N} \sum_{k=1}^{N} I(j, k)=1, \quad \sum_{j=1}^{N} \sum_{k=1}^{N} I_{d}(j, k)=1
$$

として規格化した. 3パターン記憶KPPの入力ビームとそ の遠視野像をFig. 4に示す。レーザー照射における各時間 ステップ毎の近視野パターンは, Fig. 4(a)に示すようなも のである。それらの相対強度は $1: 4: 10$ とし, ビーム間の境 界の直径は143, 248, $320 \mathrm{~mm}$ とし, 各リング面積が等し くなるように調整を行った。そして遠視野におけるそれ ぞれのビーム照射時に遠視野パターン直径が250, 175, $100 \mathrm{~mm}$ のフラットトップパターンとした。 このシミュ レーションにより得られた遠視野像をFig. 4 (b) に示す。 こ

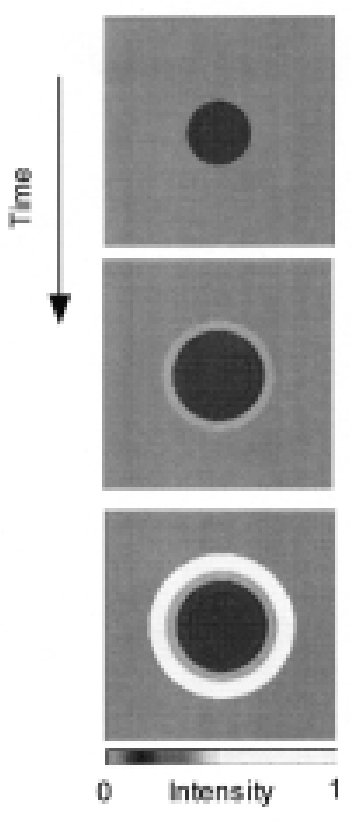

(a)near-field
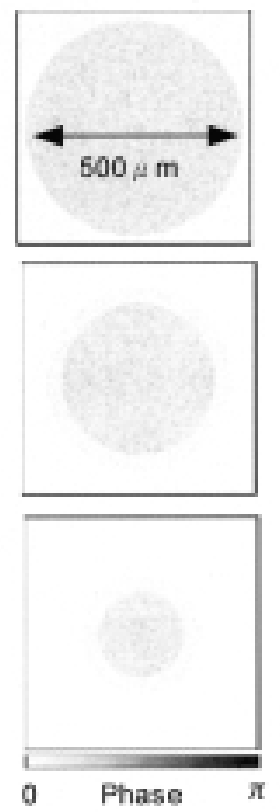

(b)far-field
Fig. 4 Dynamic focusing by using of a multi-segmented kinoform phase plate.
の結果入力ビームの口径と相対強度をうまく選べば3個の パターンを記憶することが可能であることが分かる。ま た集光パターンの評価を行った結果，エネルギー効率は $67.3 \% ， 68.0 \% ， 62.7 \%$ ，エラーは0.56，0.67，0.67という 結果が得られ，このことからもどの時間ステップのパ ターンもほぼ設計像を再生していることが確認できる. エネルギー効率は若干低いが, 爆縮効率は数倍上昇する と予想される。

\section{5. 位相誤差に耐力を有するKPP}

キノフォームを設計する際，入力ビームは完全にコ ヒーレントで位相がそろっていると仮定してきたが，実 際のビームはビーム断面内で位相が完全にそろっていな い場合が考えられる。この位相のずれを収差というが， ビーム毎に同じ収差であり，それがレーザー出力エネル ギーに依存せず経時変化もしなければ，位相回復アルゴ リズムにその収差を考慮して設計することにより解決で きる。しかし，レーザービームに高度の波面性能を求め るよりは, 比較的収差の大きなビームであっても集光パ ターンの制御が可能であることは, 将来の実用炉開発の ためにも重要である。そこで任意の波面歪にも対応でき るように，波面歪みに耐力を有する位相板の設計を試み た。これは3項の結果を発展させたものであり，位相板を 複数個に分割しそれぞれ独立して遠視野像を構成させるこ とで，1つのセグメントが受ける収差の影響を低減させる.

Fig. 5 に分割型KPP(Multi segmented KPP : MS-KPP)によ る集光強度分布制御の概念図を示す。（a）はKPPのセグメ ント化，（b)は個々のセグメントからの集光パターン，(c) はMS-KPP全体が作る集光パターンを示す. Fig. 5から分か るように，1つの位相板をいくつかの大きな集合(以下七 グメントと呼ぶ. 図の場合は $4 \times 4$ 分割)に分割する。一般 的なKPPは全体で1つのパターンを形成するのに対して, MS-KPPは個々のセグメントが遠視野像を形成し, 全体で はその重ね合わせとして作用する。ただし, 個々の強度 はインコヒーレントな重ね合わせではなく, 振幅分布の コヒーレント重ね合わせが所望の集光パターンを形成す るような設計であることに注目しなければならない.

MS-KPPの設計に利用するアルゴリズムは，基本的には 3項で述べた複数のパターンを 1 枚のKPPに記憶させる方法

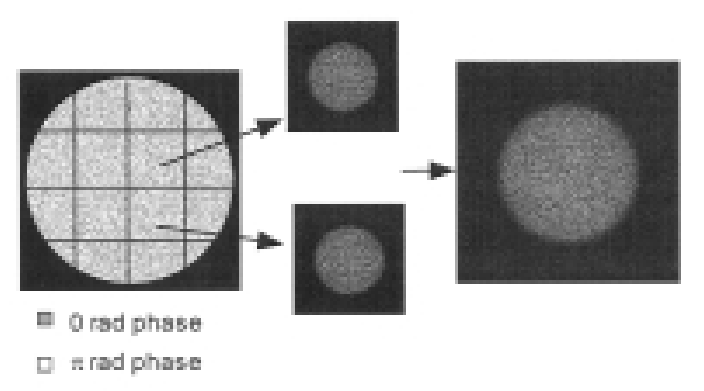

(a)

(b)

(C)

Fig. 5 Irradiance profile control using a multi-segmented kinoform phase plate. 
と同じであり，この場合はそれぞれの再生する像がすべ て同じであるという点のみ異なる。その設計アルゴリズ ムを次に示す，KPP全体のエレメント数を $N$ ，七グメント の分割数を $n \times n$ とし, 次のようなゲート関数を $1 g_{\mathrm{m}}(x, y)$ 定義する。

$$
g_{\mathrm{lm}}(x, y)=\Pi\left(\frac{x-A_{\operatorname{lm}}}{a}\right) \Pi\left(\frac{y-B_{\operatorname{lm}}}{a}\right)
$$

ただし $l=1,2, \cdots n, \quad m=1,2, \cdots n, \quad a=N / n$ で， $\left(A_{\mathrm{lm}}, B_{\mathrm{lm}}\right)$ は $(l, m)$ セグメントの座標を表し，Пは

$$
\Pi(\rho)=\left\{\begin{array}{l}
1|\rho| \leq 1 / 2 \\
0|\rho| \leq 1 / 2
\end{array}\right.
$$

を満たす rectangle関数である。このときビーム全体の複素 振幅を $f(x, y)$ とおいたとき， $(l, m)$ セグメントに関する入 力分布は

$$
f(x, y) g_{\operatorname{lm}}(x, y)
$$

で与えられるので, 位相回復アルゴリズムにおいて入 力，すなわち近視野における複素振幅を(6) とおいてその セグメントの位相分布を求める. これを $l=1,2, \cdots n, m=$ $1,2, \cdots n$ まで繰り返すことで全体の位相分布を決定する.

次にMS-KPPが理論通り位相誤差に対して耐力を有する かについて，シミュレーションを行い検討した。計算領 域全体のメッシュ数は2048, 近視野像, 遠視野像ともに フラットトップパターンを仮定しその幅をメッシュ数で 1024 とし，高速フーリエ変換を用いた。上記のアルゴリ ズムを用いて2分割のMS-KPPを設計し，比較のために分 割しない一般的なKPPも設計しておき, 歪みが付加されな い状態でのそれぞれの設計誤差 (誤差の定義は4項で定義 したものを用いる)を合わせておく. 歪みが付加されるこ とにより，その集光パターンが設計からどれだけずれる かを，分割がある場合と無い場合でシミュレーションし 比較した結果をFig. 6に示す. 付加した歪みはsin関数を用

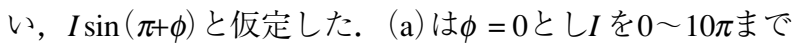
変化させた場合，（b)では $I=6 \pi$ とし $\phi$ を $0 \sim 0.5 \pi$ まで変化 させた場合の結果である。(a) (b) ともに縦軸は集光パ夕ー ンと設計パターン間の誤差，横軸は歪みの付加量を表 し, 実線が分割無しの場合, 破線が2分割の場合を示す.

Fig. 6から付加される歪み量が大きくなるにつれてMS$\mathrm{KPP}, \mathrm{KPP}$ もに集光パターンは設計パターンからの誤差 が大きくなるが，MS-KPPの方がその割合を小さくなるこ とが分かる.このことから, 分割してKPPを設計すること で，1つのセグメントが受ける位相誤差の影響を小さく し, 波面収差がある場合でも集光スポットを安定して再 生する効果が確認できた.

次に上記のシミュレーションから得られた基礎的知見 に基づいて，MS-KPPを実際のレーザーシステムへ応用し たときの効果について検討した。 大阪大学のレーザー核 融合システムでは，高効率ターゲット爆縮を行うための レーザー光として2次元スペクトル空間分布レーザー光 (2-D SSD: 2-Dimensional beam Smoothing by Spectral Dispersion) ${ }^{11)}$ が導入されている. 2-D SSDとはビーム断面 での空間的カラーサイクルが2次元的な光のことであり, $x$ 軸と $y$ 軸とでは異なった空間的カラーサイクルの異なった (a)

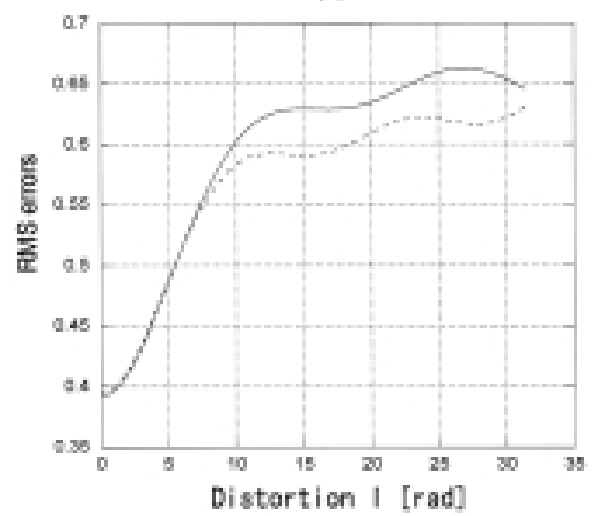

(b)

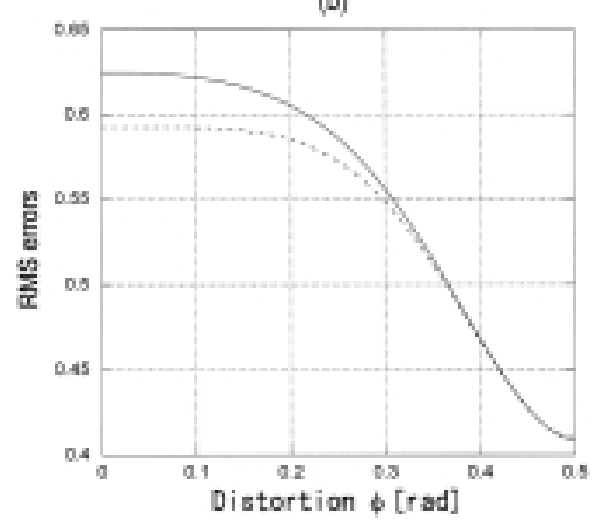

Fig. 6 The error in reconstructed far-field pattern depends on the number of segmentation.

変調周波数周期を持ち，2次元的なスペックルの移動によ りほぼ完全な2次元的平滑化が可能となる. MS-KPPに2-D SSDが入射したときの集光パターン特性についてシミュ レーションを行った. SSDの条件はバンド幅 $0.1 \mathrm{~nm}(9$ $\mathrm{GHz}) \times 0.1 \mathrm{~nm}(13 \mathrm{GHz}) ，$ スペクトル角度分散量は300 $\mu \mathrm{rad} /$ $\mathrm{nm} \times 300 \mu \mathrm{rad} / \mathrm{nm}$, 波長 $351 \mathrm{~nm}$ とした. MS-KPPの条件は $4 \times 4$ 分割, エレメントサイズ $500 \mu \mathrm{m}$, ビーム径 $320 \mathrm{~mm}$, 焦点距離5000 mm, 集光条件は径500 mmのフラットトッ プとし，デフォーカス量は-5 mmとした。このときに与え る歪みは, 現有激光XII号ターゲットおよびKDPなどの特 性を考慮して, Zernikeの収差関数の展開により, 次の3つ のZernike係数を採用した。それらは非点収差，コマ収 差, 球面収差でありこれらの係数を1とし, 線形1次結合 させたものである. Fig. 7にMS-KPPを通過した2-D SSDの 集光プロファイルとエネルギー効率を示す。波面収差が ない理想状態でのエネルギー効率は72\%である。これに 波面歪みを付加すると分割なしのKPPではエネルギー効率 が60\%まで低下するのに対して，MS-KPPを用いると集光 パターンはそれほど劣化することなく，しかもエネル ギー効率は69\%とわずかな低下にとどまった.

\section{6. まとめ}

本稿では直接照射型レーザー核融合におけるターゲッ トの球対称爆宿を効率よく行うためのレーザー光の照射 一様性の向上を目的として，位相型ホログラムによる 

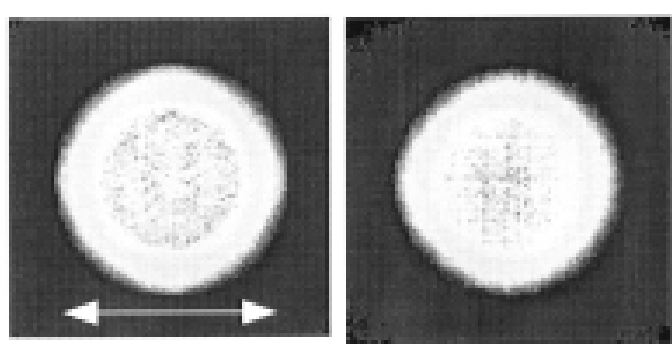

$500 \mu m$

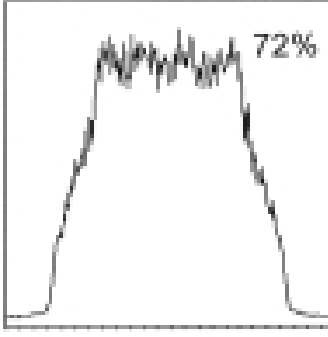

(a) Wthout distortion

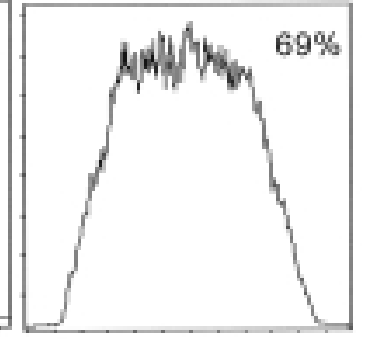

(b) With distortion
Fig. 7 Calculated far-field pattern without phase distortion and with phase distortion.

レーザー集光スポットの制御を行った. 従来, KPPにおけ る位相分布はただ一つの遠視野像を記憶しているに過ぎ なかったが，一枚のKPPに複数の集光パターンを記憶させ
る設計アルゴリズム開発し，そのアルゴリズムを用いて 設計したKPPにより本来なら静的である集光パターンを時 間的に変化させることが可能であることを，計算機シ ミュレーションにより示した。また，KPPはその原理上位 相誤差に極めて脆弱であるが，この問題を解決するため に位相板を複数個に分割しそれぞれ独立して遠視野像を 構成させることで，1つのセグメントが受ける収差の影響 を低減させ，入力位相誤差に耐力を有するMS-KPPを開発 した。これを用いることで波面収差がある場合でもエネ ルギー利用効率をほぼ維持したまま, 集光スポットを安 定して再生することが可能である.

\section{参考文献}

1) Nuckolls, L.Wood, A. Thiesson, and G. Zimmerman: Nature 239 (1972) 139.

2) Y. Kato, K. Mima, N. Miyanaga, S. Arinaga, Y. Kitagawa, M. Nakatsuka, and C. Yamanaka: Phys. Rev Lett. 53 (1984) 1057

3）大阪大学レーザー核融合研究センター：レーザー核融合炉 「光陽」概念設計, 平成6年12月 (1994).

4) S. N.Dixit, J. K. Lawson, K.R. Manes, H. T. Powell, and K. A. Nugent: Opt. Lett. 19 (1994) 417.

5) R. W. Gerchberg and W. O. Saxton: Optik 34 (1971) 275.

6) R. W. Gerchberg and W. O. Saxton: Optik 35 (1972) 237.

7) S. Kirkpatrick, C. D. Gellatt, and M. P. Vecchi: Science 220 (1983) 671.

8) J. R. Fineup: Appl. Opt. 21 (1982) 2758

9) N. Yoshikawa and T. Yatagai: Appl. Opt. 33 (1994) 863.

10) F. Wyrowski and O. Bryndahl: J. Opt. Soc. Am. A 5 (1988) 1058.

11) G. Miyaji, N. Miyanaga, S. Urushihara, K. Suzuki, S. Matsuoka, M. Nakatsuka, A. Morimoto, and T. Kobayashi: Opt. Lett. 27 (2002) 725 . 